\title{
How Does Obesity and Physical Activity Affect Aging?: Focused on Telomere as a Biomarker of Aging
}

\author{
Yun-A Shin* \\ Department of Prescription and Rehabilitation of Exercise, College of Sport Science, Dankook University, Cheonan, Korea
}

Obesity is known to continuously increase systemic inflammation and oxidative stress, leading to shorter telomere length. However, research regarding the correlation between physical activity, exercise, obesity, and telomere length is not consistent. Therefore, this review aims to summarize the effects of obesity, physical activity, and exercise on telomere length. Our search for effects of obesity, physical activity, and exercise, on telomeres was conducted using three computerized databases: Medline, PubMed, and EBSCO. Keywords in the search were "physical activity, exercise and obesity," "physical activity, exercise and telomere," and "obesity and telomere." Improving chronic inflammation and oxidative stress levels can prevent telomere attrition due to obesity. In addition, differences in the anti-aging effects of physical activity and exercise are shown in the post-middleage period, when telomere length changes, rather than in past exercise habits. Maintaining high cardiorespiratory fitness levels through regular exercise and physical activity in the post-middle-age period minimizes obesity-related diseases and helps maintain telomere length, which is an index of cell senescence.

Key words: Telomere, Obesity, Physical activity, Exercise, Cardiorespiratory fitness

\author{
Received May 6, 2019 \\ Reviewed May 23, 2019 \\ Accepted June 7, 2019 \\ *Corresponding author \\ Yun-A Shin \\ (iD) \\ https://orcid.org/0000-0002-8480-3454 \\ Department of Prescription and \\ Rehabilitation of Exercise, College of \\ Sport Science, Dankook University, \\ 119 Dandae-ro, Dongnam-gu, \\ Cheonan 31116, Korea \\ Tel: +82-41-550-3831 \\ Fax: +82-41-550-3831 \\ E-mail: shinagel@dankook.ac.kr
}

\section{INTRODUCTION}

Obesity is a major risk factor that increases mortality and the prevalence of associated age-related diseases. ${ }^{1}$ Obesity is known to continuously increase systemic inflammation and oxidative stress ${ }^{2}$, leading to shorter telomere length (TL). ${ }^{3}$

Telomeres are DNA protein complexes on the end of the chromosomes of human eukaryotic cells ${ }^{4}$ and have been reported to generally shorten with age. ${ }^{5}$ While inflammation and oxidative stress are major causes of aging, they also play an important role in telomere attrition ${ }^{6}$, and studies on the association of TL with chronic inflammation and oxidative stress have been reported. ${ }^{7}$

Recent systemic reviews have reported various results regarding the correlation between body weight status and TL, with some claiming an inverse correlation between obesity and $\mathrm{TL}^{8-10}$ and others indicating that there is no correlation. ${ }^{11,12}$ However, a metaanalysis based on cross-sectional studies reported that body mass index (BMI) and TL have an inverse association. ${ }^{7}$

Telomeres are not only affected by oxidative stress and inflammation, but also by lifestyle habits such as smoking and sedentary behavior. ${ }^{13-15}$ Recent reports have documented that physical activity is associated with TL in adults ${ }^{16-18}$, since physical activity reduces obesity, type 2 diabetes, the risk of hypertension and cancer and improves visceral fat, bone fitness, and insulin resistance. ${ }^{19,20}$

It is widely known that exercise improves cardiorespiratory function and weight loss and decreases the risk of early chronic diseases. Furthermore, the increase in oxygen consumption during exercise leads to the generation of active oxygen, which causes oxidative stress. ${ }^{21}$ Studies have shown that high intensity exercise increases oxidative stress and cause cell damage. ${ }^{22}$ Studies have also reported

Copyright (C) 2019 Korean Society for the Study of Obesity

(a) This is an Open Access article distributed under the terms of the Creative Commons Attribution Non-Commercial License (http://creativecommons.org/licenses/by-nc/4.0/) which permits unrestricted non-commercial use, distribution, and reproduction in any medium, provided the original work is properly cited 
that excessive physical activity and exercise can promote a decrease in TL. ${ }^{23}$ Thus, the correlation between physical activity, exercise, and TL is still unclear. Moreover, research findings are not consistent in this area. Some studies report that physical activity reduces the prevalence of obesity-related diseases and that it is effective in weight loss, whereas other studies report that it is ineffective. ${ }^{24,25}$ Therefore, the purpose of this review is to investigate the correlation between obesity and TL and to determine the effects of physical activity and exercise on obesity and TL through related studies.

\section{TELOMERE AND AGING}

Telomeres are composed of hexanucleotide sequences (TTAGGG) at the ends of eukaryotic chromosomes. The TL of adult mitotic cells decrease due to certain parts not being replicated during every cell division. ${ }^{26,27}$ When telomeres, which shorten after every cell division, reach a critical point, they cause arrest and malfunction of the cell cycle. This causes replicative senescence and potential genomic instability, leading to cell death. ${ }^{28}$ Therefore, telomeres reflect divisional activity (loss and stability) of each cell and are used as indicators of biological aging. ${ }^{29}$

Telomeres are affected by tissue oxidative stress and inflammation $^{30}$, and chronic inflammation promotes telomere attrition by increasing white blood cell replacement. ${ }^{31}$ In addition, oxidative stress conditions promote TL attrition in cell replication by decreasing the activity of telomerase, which is the polymerase responsible for maintaining TL. ${ }^{3}$

People with cardiovascular disease (CVD) are reported to have shorter TL compared to healthy individuals. ${ }^{32} \mathrm{TL}$ is reported to have a negative correlation with factors that cause CVD such as age, BMI, waist-to-hip ratio (WHR), hypertension, triglycerides, fasting blood glucose levels, and body fat mass. ${ }^{33}$ Hypertension causes continuous stress on blood vessels and endothelial cells and promotes remodeling, thereby increasing oxidative stress and decreasing TL. ${ }^{34}$ It has been reported that diabetes also promotes cellular aging of tissues associated with glucose transport and metabolism, thereby affecting telomere attrition..$^{35}$ The accumulation of atherosclerotic plaques in blood vessels affects the aging of vascular endothelial and smooth muscle cells resulting TL reduction. Coronary artery disease is also reported to have a negative correlation with TL. ${ }^{36}$

Many studies have also reported that shortened telomeres in leukocytes increase the prevalence and risk of disease due to aging. ${ }^{37,38}$ Short telomeres are involved in disease pathogenesis because senescent cells increase the secretion of proinflammatory cytokines and extra-cellular matrix-degrading enzymes, which promotes disease progression. ${ }^{39,40}$ Thus, telomere attrition may occur with risk factors and conditions that cause disease, and shortened telomeres may be responsible for promoting diseases caused by aging.

\section{OBESITY AND TELOMERE}

\section{The association between obesity and TL}

It is reported that obesity and TL reduction may be correlated because obesity increases oxidative stress and chronic systemic inflammation (Table 1). There is an inverse correlation between TL and BMI, WHR, total fat, and waist circumference (WC), and abdominal adipose tissue is directly related to TL attrition and promotes the aging process. ${ }^{8,9,15,16,41-49}$ Njajou et al. ${ }^{9}$ and García-Calzón et al..$^{10}$ also reported that higher WCs were associated with shorter telomeres, even after age adjustment. However, because many studies have used indirect anthropometric measurements, study results on the correlation between obesity, abdominal fat, and TL have not been consistent. Some studies have shown that telomeres correlate with obesity indices ${ }^{45-47}$, whilst some report no correlation in middle-aged people ${ }^{11,12}$ or the elderly. ${ }^{50-52}$

TLs of adipose tissue are reported to have a negative relationship with WC and adipose tissue size regardless of age. ${ }^{44}$ It has been reported that subcutaneous adipose tissue and visceral adipose tissue telomeres have a negative correlation with BMI, blood pressure, hyperlipidemia, and the size of adipose tissue. Thus, metabolic diseases associated with obesity seem to be correlated with the amount of fat tissue and TL attrition. ${ }^{42-44}$

\section{The effect of change of body weight or fat mass on telomere}

Weight gain and obesity are reported to promote telomere attrition regardless of age (Table 2). Rapid weight gain since the age of 18 has been reported to promote telomere attrition. ${ }^{11} \mathrm{~A}$ study of 2,912 Chinese women aged 40-70 years showed that TL was 
Table 1. The studies of the association between the TL and obesity

\begin{tabular}{|c|c|c|c|c|}
\hline Author (year) & Participant & LTL measurement method & Obesity marker & Association \\
\hline Lee et al. $(2011)^{8}$ & 8-80 yr, Adults ( $n=309,52 \%$ women) & qPCR & BMI, WC, HipC, \%fat, VAT & Negative \\
\hline Njajou et al. $(2012)^{9}$ & 70-79 yr, Adults ( $\mathrm{n}=2,721,51.6 \%$ women) & qPCR & \%Body fat, SAT & Negative \\
\hline Bekaert et al. $(2007)^{11}$ & $35-55 \mathrm{yr}$, Adults ( $\mathrm{n}=2,509,51.5 \%$ women) & Southern blot for WBC TRF & Body weight, BMI, WC & No \\
\hline Diaz et al. $(2010)^{12}$ & 40-64 yr, Adults ( $\mathrm{n}=317,54.9 \%$ women) & qPCR & BMI, VAT & No \\
\hline Valdes et al. $(2005)^{15}$ & 18-76 yr, Women $(n=1,122)$ & Southern blot for WBC TRF & BMl & Negative \\
\hline Cherkas et al. (2008) $)^{16}$ & 18-81 yr, Twins ( $\mathrm{n}=2,401,89.6 \%$ women) & Southern blot for WBC TRF & BMl & Negative \\
\hline Nordfjäll et al. (2008) $)^{41}$ & $26-75 \mathrm{yr}$, Adults ( $\mathrm{n}=989,48.0 \%$ women) & qPCR & BMI, body weight, WC, HipC in women & Negative \\
\hline Moreno-Navarrete et al. (2010) ${ }^{42}$ & $31-61 \mathrm{yr}$, Obese women ( $n=21$, waist $110-147 \mathrm{~cm})$ & qPCR in adipocyte & WC, adipocyte size with TL of adipocytes & Negative \\
\hline Monickaraj et al. $(2012)^{43}$ & $\begin{array}{l}\text { 34-56 yr, Obese, diabetic, and obese-diabetic } \\
\text { subjects ( } n=59,57.6 \% \text { women) }\end{array}$ & qPCR in SAT & $\mathrm{BMl}$ & Negative \\
\hline Jones et al. $(2014)^{44}$ & $\begin{array}{l}>35 \text { yr, Obese, diabetic, and obese-diabetic } \\
\text { subjects }(n=61)\end{array}$ & qPCR in SAT \& VAT & Adipose hypertrophy & Negative \\
\hline Kim et al. $(2013)^{45}$ & $>60$ yr, Women $(n=129)$ & qPCR & $\mathrm{BMI}, \mathrm{WC}$ & Negative \\
\hline Cui et al. $(2013)^{46}$ & 40-70 yr, Women $(n=2,912)$ & qPCR & $\begin{array}{l}\text { Body weight, WC, HipC, BMI, WHtR } \\
\text { WHR, height }\end{array}$ & Negative or no \\
\hline Al-Attas et al. $(2010)^{47}$ & 5-12 yr, Children ( $n=148,53.4 \%$ girls) & qPCR & WC in girls & Negative \\
\hline Fitzpatrick et al. $(2007)^{48}$ & $74.2 \pm 5.2$ yr $($ Mean $\pm S D)$, adults $(n=419)$ & Southern blot for WBC TRF & Body size, age $\leq 73 \mathrm{yr}$ & Negative or no \\
\hline Gardner et al. $(2005)^{49}$ & $21-43.5 \mathrm{yr}$, Adults ( $\mathrm{n}=70,57.1 \%$ women) & Southern blot for WBC TRF & $\mathrm{BMl}$ & Negative \\
\hline Farzaneh-Far et al. $(2010)^{50}$ & 55-78 yr, CAD ( $n=608,17.9 \%$ women) & qPCR & $\mathrm{BMl}$ & No \\
\hline Bischoff et al. $(2006)^{51}$ & 79-101 yr, Elderly twins ( $n=812,67.9 \%$ women) & qPCR & Obesity & No \\
\hline Oliveira et al. $(2018)^{52}$ & $65-74$ yr, Women $(n=83)$ & qPCR & Body weight, BMI, WC & No \\
\hline
\end{tabular}

TL, telomere length; LTL, leukocyte telomere length; qPCR, quantitative polymerase chain reaction; BMl, body mass index; WC, waist circumference; HipC, hip circumference; VAT, visceral adipose tissue; SAT, subcutaneous adipose tissue; WBC, white blood cell; TRF, terminal restriction fragment; WHtR, waist to height ratio; WHR, waist to hip ratio; SD, standard deviation; $C A D$, coronary artery disease.

shorter when weight gain after age of 50 was more than $15 \% .{ }^{46}$ Furthermore, in a study of 2,721 elderly people aged 70 to 79 years, TL was reported to be shorter with increased body weight and adipose tissue. $^{9}$

On the other hand, it was also reported that weight loss was correlated with TL elongation. TL elongation was positively correlated with weight loss, and the lengthening rate increased with increase in weight loss. ${ }^{53}$ In a study of 521 adults aged 55 to 80 years and elderly subjects who underwent the Mediterranean diet intervention for 5 years, TL was inversely correlated with changes in fat tissue including body weight, BMI, WC, and WHR, and it was reported that TL underwent elongation. ${ }^{54}$ These results suggest that weight loss prevented the decrease of TL and DNA damage. ${ }^{55}$ Oxidative stress and chronic inflammation due to obesity accelerate telomere $\operatorname{attrition}^{56}$, and telomere DNA is very sensitive to oxidative stress damage. Oxidative stress plays an important role in the decrease of $\mathrm{TL}$, because explicative senescence is considered a stress response blocking the growth of cells that have a high risk of mutation. ${ }^{22}$ Therefore, it can be suggested that telomere lengthening is correlat- ed with weight loss, decrease of inflammation and oxidative stress. Weight loss intervention not only prevents telomere shortening, but also plays an important role in telomere elongation. ${ }^{53}$ Another study showed that TLs of severely obese subjects were significantly shortened at 3, 6, 9, and 12 months after bariatric surgery and additional attrition occurred immediately after surgery, likely because of their catabolic state. ${ }^{57}$ However, there was a report that weight loss through dietary and exercise treatments for 12 months were not correlated with changes in TL. ${ }^{58}$ Thus long-term studies are needed to observe changes in TL.

Taken together, obesity is correlated with TL decreases due to chronic inflammation and oxidative stress. Obesity-related indicators (WC, WHR, or fat mass) also seem to be correlated to TL. In addition, weight loss has the effect of elongating telomeres, but weight loss through bariatric surgery is considered a catabolic state that promotes TL reduction, indicating that further studies are needed. 
Table 2. Summary of the association between the TL and weight change

\begin{tabular}{|c|c|c|c|c|c|}
\hline Author (year) & Participant & Intervention & LTL measurement method & Change of body weight & Association \\
\hline Njajou et al. $(2012)^{9}$ & $\begin{array}{l}\text { 70-79 yr, Adults ( } \mathrm{n}=2,721,51.6 \% \\
\text { women) }\end{array}$ & 7-yr Follow-up & qPCR & BMI, \%body fat loss & Positive \\
\hline Bekaert et al. $(2007)^{11}$ & $\begin{array}{l}35-55 \mathrm{yr} \text {, Adults ( } \mathrm{n}=2,509,51.5 \% \\
\text { women) }\end{array}$ & Cohort study & Southern blot for WBC TRF & $\begin{array}{l}\text { Fast weight gain since age } \\
\text { of } 18 \mathrm{yr}\end{array}$ & Negative \\
\hline Cui et al. $(2013)^{46}$ & 40-70 yr, Women $(n=2,912)$ & $\begin{array}{l}\text { Self-report (weight at } \\
\text { enrollment, age 50) }\end{array}$ & qPCR & $\begin{array}{l}\text { Loss }(\geq 5 \%) \\
\text { Stable }(\leq 5 \%) \\
\text { Gain }(5 \%-15 \%) \\
\text { Gain }(>15 \%)\end{array}$ & $\begin{array}{l}\text { Positive } \\
\text { No } \\
\text { No } \\
\text { Negative }\end{array}$ \\
\hline Carulli et al. (2016) $)^{53}$ & $\begin{array}{l}31-52 \text { yr, Obese subjects ( } n=37,62.2 \% \\
\text { women) }\end{array}$ & $\begin{array}{l}\text { Bioenteric intragastric } \\
\text { balloon }\end{array}$ & qPCR & Loss (-18.66 kg) & Positive \\
\hline O'Callaghan et al. (2009) ${ }^{54}$ & $55-80 \mathrm{yr}$, Adults ( $\mathrm{n}=521,55 \%$ women) & Mediterranean diet ( $5 \mathrm{yr})$ & qPCR & $\begin{array}{l}\text { Loss }(-1.09 \mathrm{~kg}) \\
\text { BMI }(-0.47 \mathrm{~kg}) \\
\text { WC }(-1.15 \mathrm{~cm}) \\
\text { WHR }(-0.008) \\
\text { Adiposity }\end{array}$ & $\begin{array}{l}\text { Positive } \\
\text { Positive } \\
\text { Positive } \\
\text { Positive } \\
\text { Positive }\end{array}$ \\
\hline Latifovic et al. (2016) $)^{58}$ & 50-75 yr, Women ( $\mathrm{n}=439)$ & $\begin{array}{l}\text { Diet/AE/diet+AE/CON } \\
\text { (12 mon) }\end{array}$ & qPCR & $\begin{array}{l}\operatorname{Diet}(-8.5 \%) \\
\operatorname{AE}(-2.4 \%) \\
\operatorname{Diet}+A E(-10.8 \%) \\
\operatorname{CON}(-0.8 \%)\end{array}$ & No \\
\hline
\end{tabular}

TL, telomere length; LTL, leukocyte telomere length; qPCR, quantitative polymerase chain reaction; BMl, body mass index; WBC, white blood cell; TRF, terminal restriction fragment; WC, waist circumference; WHR, waist to hip ratio; Diet, diet group; AE, aerobic exercise group; CON, control.

\section{The mechanism on association between obesity and TL}

Obesity is generally caused by the accumulation of excessive fat tissue due to excessive dietary intake and lack of physical activity. ${ }^{59}$ The accumulation of ectopic fat surrounding organs is directly correlated to insulin resistance, which is a major cause of metabolic syndrome and CVD. ${ }^{60}$ Obesity also results in the formation of reactive oxygen species and cytokines which are increased in the inflammation processes. These processes are key factors that may explain the association between obesity and telomere shortening, because inflammation induces further inflammatory reactions causing DNA damage. ${ }^{30}$ DNA migration was increased in the lymphocytes of overweight and obsese. ${ }^{61}$ These DNA damage responses are defined by the consequences of genomic instability. This is the reaction of cells to damaged DNA to prevent negative health conditions such as the initiation of mitotic senescence, arrest, repair, and cell death. ${ }^{62-64}$

Adipose tissue plays a key role in this reaction. Accumulation of visceral fat (abdominal fat) also increases fat cells and is associated with dysfunctional fat tissue. ${ }^{65}$ Fat, or adipose tissue, plays an important role in the physiological processes of tissues. It plays a role in the production of inflammatory cytokines and chemokines as well as in host defense, immunity, and injury response. ${ }^{66}$ The mechanism of a proinflammatory state accompanied by obesity may be associated with hyperplasia and hypertrophy of adipocytes, which can induce adipose tissue hypoxia. Dysfunction of adipose tissue causes secretion of prostaglandins, C-reactive proteins (CRPs), and cytokines such as interleukin-6, tumor necrosis factor alpha, and leptin, and proinflammatory biomarkers. ${ }^{67,68}$ It also lowers the level of adiponectin such as anti-atherosclerotic adipokines. This abnormal secretion of adipose tissue causes type 2 diabetes, hyperlipemia, and CVD. ${ }^{69,70}$ Obesity, metabolic syndrome, and CVD prevent malignant transformation through the activation of processes that lead to senescence and programmed cell death. These response mechanisms play a key role in the increased of inflammation via DNA damage and the activation of transcription factors as well as telomere dysfunctions. ${ }^{62,64}$

A high fat ratio in muscle also causes metabolic dysfunction by increasing the circulation of free fatty acids. Increased circulating free fatty acids increase insulin secretion to control glucose metabolism, and hyperinsulinemia reduces insulin sensitivity and causes type 2 diabetes. ${ }^{71}$ Chronic systemic inflammation also increases oxidative stress and reduces metabolic flexibility, leading to metabolic syndromes and a vicious cycle of disease $\mathrm{e}^{72}$ as well as shorter TL. 


\section{PHYSICAL ACTIVITY AND TELOMERE}

\section{Effect of physical activity on metabolic health independent from obesity}

Several studies have reported a strong correlation between obesity and physical inactivity ${ }^{73-75}$, and metabolic syndromes have also been associated with sedentary lifestyles and low cardiorespiratory fitness. ${ }^{76}$ Ostman et al. ${ }^{77}$ used a systematic review and meta-analysis to conclude that exercise was inversely correlated to body composition, blood cholesterol, fasting plasma glucose, fasting insulin, blood pressure, and clinical outcomes. Hayashino et al. ${ }^{78}$ also reported that exercise interventions affected insulin resistance, inflammatory markers/cytokines, and adipokines that cause metabolic syndrome and CVD and that there were measurable effects in the decrease of systemic inflammation as exercise duration and frequency increased.

Unlike the positive effects of exercise on disease, results of the effects of exercise on weight loss were somewhat inconsistent. According to a meta-analysis on weight loss effects by Votruba et al. ${ }^{79}$, six out of 11 studies reported weight loss in which exercise was performed without dietary control, whereas the other five studies reported no change in body weight. In another meta-analysis study, exercise alone resulted in $3 \mathrm{~kg}$ weight loss in men after 30 weeks and $1.4 \mathrm{~kg}$ weight loss in women after 12 weeks, suggesting that exercise-induced weight loss is limited. ${ }^{80}$ In a meta-analysis of 16 studies, 11 studies showed a significant decrease in body weight after exercise, but the decrease in body weight was within the range of 0.1 to $5.2 \mathrm{~kg}$ and the difference in weight loss between the exercise group compared to a control group who did not exercise was 0.6 to $3.0 \mathrm{~kg}$. The effect of weight loss for exercise alone without dietary control was very limited. ${ }^{81}$

The effect of exercise on weight loss varies according to the exercise volume. In a study that conducted high intensity ( $\geq 65 \%$ maximum oxygen consumption $\left[\mathrm{VO}_{2 \max }\right]$ ) exercise 6 to 7 days per week for at least 30 minutes to 2 hours, a 10 to $20 \mathrm{~kg}$ weight loss was reported. ${ }^{82-84}$ However, other studies have shown that weight loss was in the range of 0.2 to $1.5 \mathrm{~kg}$ despite high intensity training. ${ }^{85,86}$ Such differences in study results exist because exercise volume and weight loss do not necessarily have a measurable correlation, and the threshold of weight loss with exercise is different according to sex, individual differences, and the forms of exercise. ${ }^{87}$ Furthermore, compensatory actions such as a decrease in basal metabolism is induced because as the intake is reduced by $7,700 \mathrm{kcal}$, the amount of body weight is reduced by $70 \%$ and the amount of fat is reduced by $30 \% .88,89$

Although the weight loss effect of exercise was limited, the risk factors associated with being overweight and obese were reduced even with no change in body weight or a small weight loss of less than $5 \mathrm{~kg}{ }^{90,91}$ Exercise, regardless of weight loss, has the effect of reducing abdominal obesity, and decreasing abdominal obesity has the effect of reducing systemic inflammation and risk factors for metabolic syndrome and CVD.92,93 Exercise has anti-inflammatory effects regardless of weight loss because it reduces hypoxia in adipose tissue by increasing capillary blood flow. ${ }^{94}$ In addition, exercise training reduces CRP levels and BMI; this has been observed even without a reduction in body weight. ${ }^{95}$ The anti-inflammatory effect of exercise reduces oxidative stress, which improves glucose tolerance, insulin resistance, and fat metabolism, and has the effect of reducing blood pressure in people with metabolic diseases as well as in healthy people. ${ }^{96}$

Therefore, exercise induces a positive improvement in the prevalence of obesity and obesity-related diseases by reducing abdominal obesity, systemic inflammation, and oxidative stress, thereby reducing the risk factors of obesity-related diseases.

\section{Effect of physical activity on telomere in adults}

It is well known that regular physical activity improves cardiorespiratory function, induces some weight loss, and lowers the risk of early chronic disease. However, it has been reported that the increase of oxygen consumption during exercise increases the oxidative stress by inducing active oxygen. ${ }^{21}$ In particular, high intensity exercise greatly increases oxidative stress, resulting in cell damage. Thus, various results on the correlation between physical activity and TL have been reported.2

Many previous studies have reported that people with higher levels of physical activity have longer TLs than those who have a sedentary lifestyle (Table 3). Cherkas et al. ${ }^{16}$ reported that people with the highest physical activity had longer TLs by 200 nucleotides (7.1 vs. $6.9 \mathrm{bp}$ ) than those with the lowest physical activity, suggesting that regular physical activity can prevent aging. It has 
Table 3. Summary of the association between the TL and physical activity

\begin{tabular}{|c|c|c|c|c|}
\hline Author (year) & Subject & LTL measurement method & Intervention or factor & Association \\
\hline \multicolumn{5}{|l|}{ Physical activity \& TL } \\
\hline García-Calzón et al. (2014) 10 & $47 \mathrm{yr}, \operatorname{Men}(\mathrm{n}=782)$ & Southern blot for WBC TRF & $\begin{array}{l}\text { Low/moderate/high PA } \\
\text { Moderate: walking, cycling, skiing, gar- } \\
\text { dening, bowing, fishing, or other light } \\
\text { Ex weekly }\end{array}$ & $\begin{array}{l}\text { Proportion of shorter TRF was lowest in } \\
\text { the moderate PA }\end{array}$ \\
\hline Bekaert et al. $(2007)^{11}$ & $\begin{array}{l}35-55 \text { yr, Adults ( } n=2,509 \text {, } \\
51.5 \% \text { women) }\end{array}$ & Southern blot for WBC TRF & PA (MET x time per wk) & No association \\
\hline Cherkas et al. $(2008)^{16}$ & $\begin{array}{l}\text { 18-81 yr, Twin adults } \\
(\mathrm{n}=2,401)\end{array}$ & Southern blot for WBC TRF & Self-reported PA during the past 12 mon & Positive \\
\hline Ludlow et al. $(2008)^{17}$ & $\begin{array}{l}50-70 \mathrm{yr} \text {, Adults ( } \mathrm{n}=69, \\
50.7 \% \text { women) }\end{array}$ & qPCR in mononuclear cells & Self-reported PA during the past month & $\begin{array}{l}\text { Longer LTL of PBMC in 991-3,540 kcal/wk } \\
\text { shorter LTL of PBMC in 9,351 kcal/wk }\end{array}$ \\
\hline Latifovic et al. $(2016)^{58}$ & $\begin{array}{l}\text { 20-50 yr, Healthy adults } \\
\text { ( } n=477,57.2 \% \text { women) }\end{array}$ & qPCR & Self-reported PA during the past 7 day & Positive \\
\hline $\begin{array}{l}\text { Edwards and Loprinzi } \\
(2016)^{97}\end{array}$ & $\begin{array}{l}>20 \mathrm{yr}, \text { Adults }(\mathrm{n}=1,868, \\
49.2 \% \text { women) }\end{array}$ & qPCR & Self-reported PA during the past 30 day & Positive \\
\hline Du et al. $(2012)^{98}$ & 43-70 yr, Women ( $\mathrm{n}=7,813)$ & qPCR & Self-reported PA during the past year & Positive \\
\hline Song et al. $(2010)^{100}$ & $\begin{array}{l}\text { 18-80 yr, Healthy adults } \\
(n=80)\end{array}$ & qPCR in T-lymphocytes & Self-reported PA & $\begin{array}{l}\text { No association LTL \& PA } \\
\text { PA was negative associated with DNA } \\
\text { damage. }\end{array}$ \\
\hline Saßenroth et al. $(2015)^{101}$ & $\begin{array}{l}>61 \mathrm{yr}, \text { Adults ( } \mathrm{n}=814 \\
51.3 \% \text { women) }\end{array}$ & qPCR & $\begin{array}{l}\text { Self-reported PA during the last month } \\
\text { Longer period PA at least } 10 \mathrm{yr}\end{array}$ & $\begin{array}{l}\text { Positive association in unadjusted } \\
\text { No association after adjustments such as } \\
\text { CHD, medicine, BMl, and smoking etc. } \\
\text { PA was associated with longer LTL at over } \\
42 \mathrm{yr} \\
\text { No association at } 20-30 \mathrm{yr}\end{array}$ \\
\hline Laine et al. $(2015)^{102}$ & $\begin{array}{l}599 \text { Men (392 former } \\
\text { athletes \& } 207 \text { CON) }\end{array}$ & qPCR & Cohort study $(1985,1995$ or 2001) & No difference in LTL in late life \\
\hline Zhu et al. $(2011)^{103}$ & $\begin{array}{l}667 \text { Adolescents (14-18 yr, } \\
51 \% \text { girls) }\end{array}$ & qPCR & Vigorous PA & Positive only in girls \\
\hline \multicolumn{5}{|c|}{ TL in exercise experience \& sedentary } \\
\hline LaRocca et al. $(2010)^{18}$ & $\begin{array}{l}18-32 \text { yr vs. } 55-72 \text { yr ( } n=57 \text {, } \\
59.6 \% \text { women) }\end{array}$ & Southern blot for WBC TRF & $\begin{array}{l}\text { Endurance Ex-trained vs. SED } \\
\mathrm{VO}_{2 \max }\end{array}$ & $\begin{array}{l}\text { Longer LTL in Ex vs. SED in older } \\
\text { No difference in young and adults }\end{array}$ \\
\hline Borghini et al. $(2015)^{23}$ & $\begin{array}{l}45.4 \pm 9.2 \text { yr (Mean } \pm \text { SD), } \\
\text { adults ( } n=62,21 \% \text { women) }\end{array}$ & qPCR in saliva & Athletes ( $\mathrm{n}=20,59.4 \mathrm{~km} / \mathrm{wk}, 13.15 \mathrm{yr})$ & LTL in athletics was longer than CON \\
\hline Silva et al. $(2016)^{104}$ & $65-85 \mathrm{yr}$, Adults ( $\mathrm{n}=61)$ & Southern blot for PBMCs TRF & Regular aerobic training for at least $5 \mathrm{yr}$ & $\begin{array}{l}\text { Longer T-cell TL in the trained group vs. } \\
\text { CON }\end{array}$ \\
\hline Østhus et al. $(2012)^{105}$ & $\begin{array}{l}66-77 \text { yr, Men ( } n=20 \text {, } \\
10 \text { young, 22-27 yr; } \\
10 \text { older) }\end{array}$ & qPCR in skeletal muscle & $\begin{array}{l}\text { Endurance athletes (EA, } n=10 \text {, long dis- } \\
\text { tance } \& \text { track running competitions) } \\
\text { vs. moderate PA (MPA, } n=10 \text { ) }\end{array}$ & $\begin{array}{l}\text { Longer } L R L \text { in older } E A \text { vs. MPA } \\
\text { No difference of } L R L \text { in young } E A \text { vs. MPA }\end{array}$ \\
\hline Denham et al. $(2013)^{106}$ & $>30 \mathrm{yr}, \operatorname{Men}(\mathrm{n}=123)$ & qPCR & $\begin{array}{l}\text { Ultra-marathon runner ( } \mathrm{n}=67,40-100 \\
\mathrm{~km} / \mathrm{wk}, \geq 2 \mathrm{yr})\end{array}$ & Longer LTL in runners vs. CON \\
\hline Mathur et al. $(2013)^{107}$ & 15 yr, Boys $(n=32)$ & $\begin{array}{l}\text { qPCR in lymphocyte and } \\
\text { granulocyte }\end{array}$ & $\begin{array}{l}\text { Marathon runner ( } n=17) \text { vs. CON } \\
(n=15)\end{array}$ & No difference \\
\hline Shin et al. $(2008)^{108}$ & $47 \mathrm{yr}$, Obese women $(n=16)$ & Southern blot for WBC TRF & $\mathrm{AE}$ ( 3 day/wk, 60 min, 6 mon) & No difference \\
\hline Friedenreich et al. $(2018)^{109}$ & $\begin{array}{l}\text { 50-60 yr, Postmenopausal } \\
\text { women ( } n=212 ; 99 \text { Ex vs. } \\
113 \text { CON) }\end{array}$ & qPCR & $\mathrm{AE}$ (5 day/wk, 12 mon) & No difference \\
\hline
\end{tabular}

TL, telomere length; LTL, leukocyte telomere length; WBC, white blood cell; TRF, terminal restriction fragment; PA, physical activity; Ex, exercise group; MET, metabolic equivalent of task; qPCR, quantitative polymerase chain reaction; PBMC, peripheral blood mononuclear cell; CHD, chronic heart disease; BMI, body mass index; CON, control group; SED, sedentary; $\mathrm{VO}_{2 \max }$, maximum oxygen consumption; $\mathrm{SD}$, standard deviation; $\mathrm{EA}$, endurance athletes; LRL, long distance \& track running competitions; MPA, moderate physical activity; $A E_{\text {, }}$ aerobic exercise. 
also been reported that the higher the level of physical activity and the amount of physical activity per week, the longer the TL is. ${ }^{58,97,98}$

However, while physical activity of moderate intensity (991$3,540 \mathrm{kcal} / \mathrm{wk}$ ) results in longer TLs, too much physical activity $(9,351 \mathrm{kcal} / \mathrm{wk})$ can result in shorter TLs. ${ }^{17}$ In another study, the TL reduction rate of a moderate intensity exercise group was lower than that of the high intensity and control groups. ${ }^{99}$ Some studies reported that physical activity was negatively correlated with levels of DNA damage, but not with $\mathrm{TL}^{100}$, whilst others reported that there was no correlation between TL and physical activity. ${ }^{11}$ As such, study results are inconsistent. Regarding the different study results, the differences in TL and physical activity were found to be different according to age, periods of physical activity, lifestyles, and medical histories. ${ }^{101,102}$ In teenagers, the correlation between physical activity and TL was only observed in female students. ${ }^{103}$ Moreover, there was no difference in TL and physical activity in people aged 20 to 30 years, but there was a difference in people who were over 42 years old. In particular, it has been reported that there was a difference according to the presence of obesity, illness, and smoking when the period of physical activity was over 10 years. ${ }^{101}$

\section{The different effects of physical activity on telomere according to age}

In studies where TL changes during long-term regular exercise were observed, many reported that TL was longer in the regular exercise group than in the non-exercise group (Table 3). ${ }^{23,104-106}$ However, TL according to long-term exercise varied according to age. In the 15-year-old group, there was no difference in TL between marathon runners and ordinary individuals ${ }^{107}$, and no difference in the young group (18-32 years). However, in the middle aged group (55-72 years) that exercised regularly, TL was reported to be 900 bp longer than that of the sedentary group. Thus, the study reported that exercise habits in the post-middle-age period were effective in preventing aging. ${ }^{18}$ However, after premenopausal women exercised three times a week for 6 months, and menopausal women aged 50 to 60 years exercised five times a week for 12 months (supervised exercise, three times a week), no difference between the exercise group and the non-exercise group was reported. Thus, the correlation between exercise and TL differs among women depending on exercise training periods and menopause. ${ }^{108,109}$

In a study of the relationship between cardiorespiratory fitness and TL, it was reported that the maximum oxygen uptake and TL were significantly correlated (Table 4). ${ }^{110,111}$ However, the positive correlation between cardiorespiratory fitness and TL also showed age-related differences such as a correlation with long-term regular exercise. There was no correlation between cardiorespiratory fitness and TL in the 15-year-old adolescent group ${ }^{106}$ or in the young (18-32 years) group. ${ }^{18,97}$ Differences were observed only in the middle-aged group (55-72 years). ${ }^{18}$ In a study of 582 elderly people aged 60 years and older, TL was reported to be longer in persons showing good performance in sitting and standing, and the TL decrease was reported to be less than $0.9 \mathrm{bp}$ each year for every 1 second decrease in performance. ${ }^{112}$ In addition, a study correlating leg muscle strength and TL in adults over 50 years of age re-

Table 4. Summary of the association between the TL and cardiorespiratory fitness

\begin{tabular}{|c|c|c|c|c|}
\hline Author (year) & Subject & LTL measurement method & Intervention or factor & Association \\
\hline LaRocca et al. (2010)18 & $\begin{array}{l}\text { 18-32 yr vs. } 55-72 \text { yr }(n=57,59.6 \% \\
\text { women) }\end{array}$ & Southern blot for WBC TRF & Maximal Ex test $\left(\mathrm{VO}_{2 \max }\right)$ & $\begin{array}{l}\text { LTL was positively associated with } \\
V 0_{2 \max } \text { in older adults }\end{array}$ \\
\hline Edwards and Loprinzi (2016) & $>20 \mathrm{yr}$, Adults ( $\mathrm{n}=1,868,49.2 \%$ women) & qPCR & Submaximal treadmill test (CRF) & No association \\
\hline Mathur et al. $(2013)^{107}$ & $15 \mathrm{yr}$, Boys $(\mathrm{n}=32)$ & Lymphocyte TL & Maximal Ex test $\left(\mathrm{VO}_{2 \max }\right)$ & No association \\
\hline Mason et al. $(2013)^{110}$ & $\begin{array}{l}\text { 50-75 yr, Postmenopausal women } \\
(\mathrm{n}=439)\end{array}$ & qPCR & Maximal Ex test $\left(\mathrm{VO}_{2 \max }\right)$ & $\begin{array}{l}\text { LTL was positively associated with } \\
\text { VO } 0_{\text {max }}\end{array}$ \\
\hline Krauss et al. $(2011)^{111}$ & 944 Adults with CVD (20\% women) & qPCR & Maximal Ex test (CRF) & $\begin{array}{l}\text { High CRF ( > } 7 \text { METs) had two-fold } \\
\text { longer LTL vs. low CRF }\end{array}$ \\
\hline Soares-Miranda et al. $(2015)^{112}$ & $73.5 \mathrm{yr}$, Adults ( $\mathrm{n}=582,62 \%$ women) & Southern blot for WBC TRF & $\begin{array}{l}\text { 15-ft walk (sec), grip strength (kg), } \\
\text { chair stands (sec) }\end{array}$ & $\begin{array}{l}\text { A better chair test performance in } \\
\text { longer LTL } \\
\text { Changes chair time was associated } \\
\text { with changes in LTL }\end{array}$ \\
\hline
\end{tabular}

TL, telomere length; LTL, leukocyte telomere length; WBC, white blood cell; TRF, terminal restriction fragment; Ex, exercise; $\mathrm{VO}_{2 m a x}$, maximum oxygen consumption; qPCR, quantitative polymerase chain reaction; CRF, cardiorespiratory fitness; CVD, cardiovascular disease; METs, metabolic equivalent of task. 
ported that telomere attrition was reduced by as much as $9 \%$ with every $50 \mathrm{~N}$ increase in leg strength ${ }^{113}$, with a possible explanation being that leg muscle strength and exercise performance ability are fitness factors that can be maintained or improved through regular physical activity and exercise, which affect cardiorespiratory fitness.

\section{CONCLUSION}

Telomerase maintains TL according to age. The activity of telomerase gradually decreases between 4 and 39 years of age and, after the age of 40 , telomerase activity is not observed in $35 \%$ of the population. ${ }^{114}$ Furthermore, there is a more positive effect of regular physical activity in late middle age, when changes in TL are observed. In particular, considering that it was reported that past athletic experience does not affect TL after $10-20$ years $^{102}$, regular exercise at the time of telomere attrition could be an important precaution to prevent cell senescence.

\section{CONFLICTS OF INTEREST}

The author declares no conflict of interest.

\section{ACKNOWLEDGMENTS}

The author thank the laboratory members for their assistance in writing this article.

\section{REFERENCES}

1. Reilly JJ, Kelly J. Long-term impact of overweight and obesity in childhood and adolescence on morbidity and premature mortality in adulthood: systematic review. Int J Obes (Lond) 2011;35:891-8.

2. Furukawa S, Fujita T, Shimabukuro M, Iwaki M, Yamada Y, Nakajima Y, et al. Increased oxidative stress in obesity and its impact on metabolic syndrome. J Clin Invest 2004;114: 1752-61.

3. Kurz DJ, Decary S, Hong Y, Trivier E, Akhmedov A, Erusalimsky JD. Chronic oxidative stress compromises telomere integrity and accelerates the onset of senescence in human endothelial cells. J Cell Sci 2004;117(Pt 11):2417-26.

4. Moyzis RK, Buckingham JM, Cram LS, Dani M, Deaven $\mathrm{LL}$, Jones $\mathrm{MD}$, et al. A highly conserved repetitive DNA sequence, (TTAGGG)n, present at the telomeres of human chromosomes. Proc Natl Acad Sci U S A 1988;85:6622-6.

5. Njajou OT, Cawthon RM, Damcott CM, Wu SH, Ott S, Garant MJ, et al. Telomere length is paternally inherited and is associated with parental lifespan. Proc Natl Acad Sci U S A 2007; 104:12135-9.

6. Minamino T, Orimo M, Shimizu I, Kunieda T, Yokoyama M, Ito $\mathrm{T}$, et al. A crucial role for adipose tissue p53 in the regulation of insulin resistance. Nat Med 2009;15:1082-7.

7. Müezzinler A, Zaineddin AK, Brenner H. Body mass index and leukocyte telomere length in adults: a systematic review and meta-analysis. Obes Rev 2014;15:192-201.

8. Lee M, Martin H, Firpo MA, Demerath EW. Inverse association between adiposity and telomere length: The Fels Longitudinal Study. Am J Hum Biol 2011;23:100-6.

9. Njajou OT, Cawthon RM, Blackburn EH, Harris TB, Li R, Sanders JL, et al. Shorter telomeres are associated with obesity and weight gain in the elderly. Int J Obes (Lond) 2012; 36:1176-9.

10. García-Calzón S, Gea A, Razquin C, Corella D, LamuelaRaventós RM, Martínez JA, et al. Longitudinal association of telomere length and obesity indices in an intervention study with a Mediterranean diet: the PREDIMED-NAVARRA trial. Int J Obes (Lond) 2014;38:177-82.

11. Bekaert S, De Meyer T, Rietzschel ER, De Buyzere ML, De Bacquer D, Langlois M, et al. Telomere length and cardiovascular risk factors in a middle-aged population free of overt cardiovascular disease. Aging Cell 2007;6:639-47.

12. Diaz VA, Mainous AG, Player MS, Everett CJ. Telomere length and adiposity in a racially diverse sample. Int J Obes (Lond) 2010;34:261-5.

13. Epel ES, Blackburn EH, Lin J, Dhabhar FS, Adler NE, Morrow JD, et al. Accelerated telomere shortening in response to life stress. Proc Natl Acad Sci U S A 2004;101:17312-5.

14. Demissie S, Levy D, Benjamin EJ, Cupples LA, Gardner JP, Herbert A, et al. Insulin resistance, oxidative stress, hypertension, and leukocyte telomere length in men from the Fram- 
ingham Heart Study. Aging Cell 2006;5:325-30.

15. Valdes AM, Andrew T, Gardner JP, Kimura M, Oelsner E, Cherkas LF, et al. Obesity, cigarette smoking, and telomere length in women. Lancet 2005;366:662-4.

16. Cherkas LF, Hunkin JL, Kato BS, Richards JB, Gardner JP, Surdulescu GL, et al. The association between physical activity in leisure time and leukocyte telomere length. Arch Intern Med 2008;168:154-8.

17. Ludlow AT, Zimmerman JB, Witkowski S, Hearn JW, Hatfield BD, Roth SM. Relationship between physical activity level, telomere length, and telomerase activity. Med Sci Sports Exerc 2008;40:1764-71.

18. LaRocca TJ, Seals DR, Pierce GL. Leukocyte telomere length is preserved with aging in endurance exercise-trained adults and related to maximal aerobic capacity. Mech Ageing Dev 2010;131:165-7.

19. Barbeau P, Johnson MH, Howe CA, Allison J, Davis CL, Gutin $\mathrm{B}$, et al. Ten months of exercise improves general and visceral adiposity, bone, and fitness in black girls. Obesity (Silver Spring) 2007;15:2077-85.

20. Davis C, Boyle CA, Gutin B. Dose-response effect of aerobic exercise training on insulin resistance in overweight children. Obesity 2007;15(Suppl):A19.

21. Kojda G, Hambrecht R. Molecular mechanisms of vascular adaptations to exercise: physical activity as an effective antioxidant therapy? Cardiovasc Res 2005;67:187-97.

22. Tanaka T, Nakamura H, Yodoi J, Bloom ET. Redox regulation of the signaling pathways leading to eNOS phosphorylation. Free Radic Biol Med 2005;38:1231-42.

23. Borghini A, Giardini G, Tonacci A, Mastorci F, Mercuri A, Mrakic-Sposta S, et al. Chronic and acute effects of endurance training on telomere length. Mutagenesis 2015;30:711-6.

24. Avenell A, Brown TJ, McGee MA, Campbell MK, Grant $\mathrm{AM}$, Broom J, et al. What interventions should we add to weight reducing diets in adults with obesity? A systematic review of randomized controlled trials of adding drug therapy, exercise, behaviour therapy or combinations of these interventions. J Hum Nutr Diet 2004;17:293-316.

25. Curioni CC, Lourenço PM. Long-term weight loss after diet and exercise: a systematic review. Int J Obes (Lond) 2005;
29:1168-74.

26. Counter CM, Avilion AA, LeFeuvre CE, Stewart NG, Greider CW, Harley CB, et al. Telomere shortening associated with chromosome instability is arrested in immortal cells which express telomerase activity. EMBO J 1992;11:1921-9.

27. Harley CB, Futcher AB, Greider CW. Telomeres shorten during ageing of human fibroblasts. Nature 1990;345:458-60.

28. Hayflick L. The limited in vitro lifetime of human diploid cell strains. Exp Cell Res 1965;37:614-36.

29. Blackburn EH. Structure and function of telomeres. Nature 1991;350:569-73.

30. Wolkowitz OM, Mellon SH, Epel ES, Lin J, Dhabhar FS, Su Y, et al. Leukocyte telomere length in major depression: correlations with chronicity, inflammation and oxidative stress: preliminary findings. PLoS One 2011;6:e17837.

31. Samani NJ, Boultby R, Butler R, Thompson JR, Goodall AH. Telomere shortening in atherosclerosis. Lancet 2001; 358:472-3.

32. Lusis AJ. Atherosclerosis. Nature 2000;407:233-41.

33. Kim S, Parks CG, DeRoo LA, Chen H, Taylor JA, Cawthon $\mathrm{RM}$, et al. Obesity and weight gain in adulthood and telomere length. Cancer Epidemiol Biomarkers Prev 2009;18:816-20.

34. Hamet P, Thorin-Trescases N, Moreau P, Dumas P, Tea BS, deBlois $\mathrm{D}$, et al. Workshop: excess growth and apoptosis: is hypertension a case of accelerated aging of cardiovascular cells? Hypertension 2001;37(2 Pt 2):760-6.

35. Nolan CJ, Damm P, Prentki M. Type 2 diabetes across generations: from pathophysiology to prevention and management. Lancet 2011;378:169-81.

36. Obana N, Takagi S, Kinouchi Y, Tokita Y, Sekikawa A, Takahashi S, et al. Telomere shortening of peripheral blood mononuclear cells in coronary disease patients with metabolic disorders. Intern Med 2003;42:150-3.

37. Epel ES. Psychological and metabolic stress: a recipe for accelerated cellular aging? Hormones (Athens) 2009;8:7-22.

38. Zee RY, Castonguay AJ, Barton NS, Germer S, Martin M. Mean leukocyte telomere length shortening and type 2 diabetes mellitus: a case-control study. Transl Res 2010;155: 166-9.

39. Blackburn EH. Telomeres and telomerase: their mechanisms 
of action and the effects of altering their functions. FEBS Lett 2005;579:859-62.

40. Effros RB, Dagarag M, Spaulding C, Man J. The role of CD8+ T-cell replicative senescence in human aging. Immunol Rev 2005;205:147-57.

41. Nordfjäll K, Eliasson M, Stegmayr B, Melander O, Nilsson P, Roos G. Telomere length is associated with obesity parameters but with a gender difference. Obesity (Silver Spring) 2008; 16:2682-9.

42. Moreno-Navarrete JM, Ortega F, Sabater M, Ricart W, Fernández-Real JM. Telomere length of subcutaneous adipose tissue cells is shorter in obese and formerly obese subjects. Int J Obes (Lond) 2010;34:1345-8.

43. Monickaraj F, Gokulakrishnan K, Prabu P, Sathishkumar C, Anjana RM, Rajkumar JS, et al. Convergence of adipocyte hypertrophy, telomere shortening and hypoadiponectinemia in obese subjects and in patients with type 2 diabetes. Clin Biochem 2012;45:1432-8.

44. Jones DA, Prior SL, Barry JD, Caplin S, Baxter JN, Stephens JW. Changes in markers of oxidative stress and DNA damage in human visceral adipose tissue from subjects with obesity and type 2 diabetes. Diabetes Res Clin Pract 2014;106: 627-33.

45. Kim JH, Kim HK, Ko JH, Bang H, Lee DC. The relationship between leukocyte mitochondrial DNA copy number and telomere length in community-dwelling elderly women. PLoS One 2013;8:e67227.

46. Cui Y, Gao YT, Cai Q, Qu S, Cai H, Li HL, et al. Associations of leukocyte telomere length with body anthropometric indices and weight change in Chinese women. Obesity (Silver Spring) 2013;21:2582-8.

47. Al-Attas OS, Al-Daghri N, Bamakhramah A, Shaun Sabico S, McTernan P, Huang TT. Telomere length in relation to insulin resistance, inflammation and obesity among Arab youth. Acta Paediatr 2010;99:896-9.

48. Fitzpatrick AL, Kronmal RA, Gardner JP, Psaty BM, Jenny NS, Tracy RP, et al. Leukocyte telomere length and cardiovascular disease in the cardiovascular health study. Am J Epidemiol 2007;165:14-21.

49. Gardner JP, Li S, Srinivasan SR, Chen W, Kimura M, Lu X, et al. Rise in insulin resistance is associated with escalated telomere attrition. Circulation 2005;111:2171-7.

50. Farzaneh-Far R, Lin J, Epel E, Lapham K, Blackburn E, Whooley MA. Telomere length trajectory and its determinants in persons with coronary artery disease: longitudinal findings from the heart and soul study. PLoS One 2010;5:e8612.

51. Bischoff C, Petersen HC, Graakjaer J, Andersen-Ranberg K, Vaupel JW, Bohr VA, et al. No association between telomere length and survival among the elderly and oldest old. Epidemiology 2006;17:190-4.

52. Oliveira BS, Pirkle CM, Zunzunegui MV, Batistuzzo de Medeiros SR, Thomasini RL, Guerra RO. Leukocyte telomere length and chronic conditions in older women of northeast brazil: a cross-sectional study. Cells 2018;7:E193.

53. Carulli L, Anzivino C, Baldelli E, Zenobii MF, Rocchi MB, Bertolotti M. Telomere length elongation after weight loss intervention in obese adults. Mol Genet Metab 2016;118: $138-42$.

54. O'Callaghan NJ, Clifton PM, Noakes M, Fenech M. Weight loss in obese men is associated with increased telomere length and decreased abasic sites in rectal mucosa. Rejuvenation Res 2009;12:169-76.

55. Zhang J, Rane G, Dai X, Shanmugam MK, Arfuso F, Samy $\mathrm{RP}$, et al. Ageing and the telomere connection: an intimate relationship with inflammation. Ageing Res Rev 2016;25:5569.

56. von Zglinicki T. Oxidative stress shortens telomeres. Trends Biochem Sci 2002;27:339-44.

57. Formichi C, Cantara S, Ciuoli C, Neri O, Chiofalo F, Selmi F, et al. Weight loss associated with bariatric surgery does not restore short telomere length of severe obese patients after 1 year. Obes Surg 2014;24:2089-93.

58. Latifovic L, Peacock SD, Massey TE, King WD. The influence of alcohol consumption, cigarette smoking, and physical activity on leukocyte telomere length. Cancer Epidemiol Biomarkers Prev 2016;25:374-80.

59. Lau DC, Douketis JD, Morrison KM, Hramiak IM, Sharma AM, Ur E, et al. 2006 Canadian clinical practice guidelines on the management and prevention of obesity in adults and children [summary]. CMAJ 2007;176:S1-13. 
60. Sironi AM, Gastaldelli A, Mari A, Ciociaro D, Positano V, Buzzigoli E, et al. Visceral fat in hypertension: influence on insulin resistance and beta-cell function. Hypertension 2004; 44:127-33.

61. Pálmai-Pallag T, Bachrati CZ. Inflammation-induced DNA damage and damage-induced inflammation: a vicious cycle. Microbes Infect 2014;16:822-32.

62. Erol A. Systemic DNA damage response and metabolic syndrome as a premalignant state. Curr Mol Med 2010;10:32134.

63. Caldon CE. Estrogen signaling and the DNA damage response in hormone dependent breast cancers. Front Oncol 2014;4:106.

64. Shimizu I, Yoshida Y, Suda M, Minamino T. DNA damage response and metabolic disease. Cell Metab 2014;20:967-77.

65. Huth C, Pigeon É, Riou MÈ, St-Onge J, Arguin H, Couillard E, et al. Fitness, adiposopathy, and adiposity are independent predictors of insulin sensitivity in middle-aged men without diabetes. J Physiol Biochem 2016;72:435-44.

66. Dusserre E, Moulin P, Vidal H. Differences in mRNA expression of the proteins secreted by the adipocytes in human subcutaneous and visceral adipose tissues. Biochim Biophys Acta 2000;1500:88-96.

67. Ellulu MS, Khaza'ai H, Rahmat A, Patimah I, Abed Y. Obesity can predict and promote systemic inflammation in healthy adults. Int J Cardiol 2016;215:318-24.

68. Das UN. Is obesity an inflammatory condition? Nutrition 2001;17:953-66.

69. Guarner V, Rubio-Ruiz ME. Low-grade systemic inflammation connects aging, metabolic syndrome and cardiovascular disease. Interdiscip Top Gerontol 2015;40:99-106.

70. Marsland AL, McCaffery JM, Muldoon MF, Manuck SB. Systemic inflammation and the metabolic syndrome among middle-aged community volunteers. Metabolism 2010;59: 1801-8.

71. Eaton SB, Eaton SB. Physical inactivity, obesity, and type 2 diabetes: an evolutionary perspective. Res Q Exerc Sport 2017;88:1-8.

72. Nunn AV, Guy GW, Brodie JS, Bell JD. Inflammatory modulation of exercise salience: using hormesis to return to a healthy lifestyle. Nutr Metab (Lond) 2010;7:87.

73. Telford RD. Low physical activity and obesity: causes of chronic disease or simply predictors? Med Sci Sports Exerc 2007;39:1233-40.

74. Bullock VE, Griffiths P, Sherar LB, Clemes SA. Sitting time and obesity in a sample of adults from Europe and the USA. Ann Hum Biol 2017;44:230-6.

75. Roda C, Charreire H, Feuillet T, Mackenbach JD, Compernolle S, Glonti K, et al. Lifestyle correlates of overweight in adults: a hierarchical approach (the SPOTLIGHT project). Int J Behav Nutr Phys Act 2016;13:114.

76. Lakka TA, Laaksonen DE, Lakka HM, Männikkö N, Niskanen LK, Rauramaa R, et al. Sedentary lifestyle, poor cardiorespiratory fitness, and the metabolic syndrome. Med Sci Sports Exerc 2003;35:1279-86.

77. Ostman C, Smart NA, Morcos D, Duller A, Ridley W, Jewiss $\mathrm{D}$. The effect of exercise training on clinical outcomes in patients with the metabolic syndrome: a systematic review and meta-analysis. Cardiovasc Diabetol 2017;16:110.

78. Hayashino Y, Jackson JL, Hirata T, Fukumori N, Nakamura F, Fukuhara S, et al. Effects of exercise on C-reactive protein, inflammatory cytokine and adipokine in patients with type 2 diabetes: a meta-analysis of randomized controlled trials. Metabolism 2014;63:431-40.

79. Votruba SB, Horvitz MA, Schoeller DA. The role of exercise in the treatment of obesity. Nutrition 2000;16:179-88.

80. Garrow JS, Summerbell CD. Meta-analysis: effect of exercise, with or without dieting, on the body composition of overweight subjects. Eur J Clin Nutr 1995;49:1-10.

81. Catenacci VA, Wyatt HR. The role of physical activity in producing and maintaining weight loss. Nat Clin Pract Endocrinol Metab 2007;3:518-29.

82. Lee L, Kumar S, Leong LC. The impact of five-month basic military training on the body weight and body fat of 197 moderately to severely obese Singaporean males aged 17 to 19 years. Int J Obes Relat Metab Disord 1994;18:105-9.

83. Van Loan MD, Keim NL, Barbieri TF, Mayclin PL. The effects of endurance exercise with and without a reduction of energy intake on fat-free mass and the composition of fat-free mass in obese women. Eur J Clin Nutr 1994;48:408-15. 
84. Keim NL, Barbieri TF, Van Loan MD, Anderson BL. Energy expenditure and physical performance in overweight women: response to training with and without caloric restriction. Metabolism 1990;39:651-8.

85. Church TS, Earnest CP, Thompson AM, Priest EL, Rodarte RQ Saunders T, et al. Exercise without weight loss does not reduce C-reactive protein: the INFLAME study. Med Sci Sports Exerc 2010;42:708-16.

86. Kraus WE, Houmard JA, Duscha BD, Knetzger KJ, Wharton $\mathrm{MB}, \mathrm{McCartney} \mathrm{JS}$, et al. Effects of the amount and intensity of exercise on plasma lipoproteins. N Engl J Med 2002;347: 1483-92.

87. Rosenkilde M, Auerbach P, Reichkendler MH, Ploug T, Stallknecht BM, Sjödin A. Body fat loss and compensatory mechanisms in response to different doses of aerobic exercise: a randomized controlled trial in overweight sedentary males. Am J Physiol Regul Integr Comp Physiol 2012;303: R571-9.

88. Church TS, Martin CK, Thompson AM, Earnest CP, Mikus $\mathrm{CR}$, Blair SN. Changes in weight, waist circumference and compensatory responses with different doses of exercise among sedentary, overweight postmenopausal women. PLoS One 2009; 4:e4515.

89. King NA, Hopkins M, Caudwell P, Stubbs RJ, Blundell JE. Individual variability following 12 weeks of supervised exercise: identification and characterization of compensation for exercise-induced weight loss. Int J Obes (Lond) 2008;32: $177-84$.

90. Church TS, Earnest CP, Skinner JS, Blair SN. Effects of different doses of physical activity on cardiorespiratory fitness among sedentary, overweight or obese postmenopausal women with elevated blood pressure: a randomized controlled trial. JAMA 2007;297:2081-91.

91. Johannsen NM, Swift DL, Lavie CJ, Earnest CP, Blair SN, Church TS. Categorical analysis of the impact of aerobic and resistance exercise training, alone and in combination, on cardiorespiratory fitness levels in patients with type 2 diabetes: results from the HART-D study. Diabetes Care 2013;36: 3305-12.

92. Pedersen BK, Saltin B. Exercise as medicine: evidence for prescribing exercise as therapy in 26 different chronic diseases. Scand J Med Sci Sports 2015;25 Suppl 3:1-72.

93. Stewart KJ, Bacher AC, Turner K, Lim JG, Hees PS, Shapiro EP, et al. Exercise and risk factors associated with metabolic syndrome in older adults. Am J Prev Med 2005;28:9-18.

94. You T, Arsenis NC, Disanzo BL, Lamonte MJ. Effects of exercise training on chronic inflammation in obesity: current evidence and potential mechanisms. Sports Med 2013;43: 243-56.

95. Kasapis C, Thompson PD. The effects of physical activity on serum C-reactive protein and inflammatory markers: a systematic review. J Am Coll Cardiol 2005;45:1563-9.

96. Golbidi S, Frisbee JC, Laher I. Chronic stress impacts the cardiovascular system: animal models and clinical outcomes. Am J Physiol Heart Circ Physiol 2015;308:H1476-98.

97. Edwards MK, Loprinzi PD. Sedentary behavior, physical activity and cardiorespiratory fitness on leukocyte telomere length. Health Promot Perspect 2016;7:22-7.

98. Du M, Prescott J, Kraft P, Han J, Giovannucci E, Hankinson SE, et al. Physical activity, sedentary behavior, and leukocyte telomere length in women. Am J Epidemiol 2012;175:414-22.

99. Savela S, Saijonmaa O, Strandberg TE, Koistinen P, Strandberg AY, Tilvis RS, et al. Physical activity in midlife and telomere length measured in old age. Exp Gerontol 2013;48:81-4.

100. Song Z, von Figura G, Liu Y, Kraus JM, Torrice C, Dillon P, et al. Lifestyle impacts on the aging-associated expression of biomarkers of DNA damage and telomere dysfunction in human blood. Aging Cell 2010;9:607-15.

101. Saßenroth D, Meyer A, Salewsky B, Kroh M, Norman K, Steinhagen-Thiessen E, et al. Sports and exercise at different ages and leukocyte telomere length in later life: data from the Berlin aging study II (BASE-II). PLoS One 2015;10: e0142131.

102. Laine MK, Eriksson JG, Kujala UM, Raj R, Kaprio J, Bäckmand HM, et al. Effect of intensive exercise in early adult life on telomere length in later life in men. J Sports Sci Med 2015; 14:239-45.

103. Zhu H, Wang X, Gutin B, Davis CL, Keeton D, Thomas J, et al. Leukocyte telomere length in healthy Caucasian and African-American adolescents: relationships with race, sex, 
adiposity, adipokines, and physical activity. J Pediatr 2011; 158:215-20.

104. Silva LC, de Araújo AL, Fernandes JR, Matias Mde S, Silva PR, Duarte AJ, et al. Moderate and intense exercise lifestyles attenuate the effects of aging on telomere length and the survival and composition of $\mathrm{T}$ cell subpopulations. Age (Dordr) 2016;38:24.

105. Østhus IB, Sgura A, Berardinelli F, Alsnes IV, Brønstad E, Rehn $\mathrm{T}$, et al. Telomere length and long-term endurance exercise: does exercise training affect biological age? A pilot study. PLoS One 2012;7:e52769.

106. Denham J, Nelson CP, O’Brien BJ, Nankervis SA, Denniff M, Harvey JT, et al. Longer leukocyte telomeres are associated with ultra-endurance exercise independent of cardiovascular risk factors. PLoS One 2013;8:e69377.

107. Mathur S, Ardestani A, Parker B, Cappizzi J, Polk D, Thompson PD. Telomere length and cardiorespiratory fitness in marathon runners. J Investig Med 2013;61:613-5.

108. Shin YA, Lee JH, Song W, Jun TW. Exercise training improves the antioxidant enzyme activity with no changes of telomere length. Mech Ageing Dev 2008;129:254-60.

109. Friedenreich CM, Wang Q, Ting NS, Brenner DR, Conroy SM, McIntyre JB, et al. Effect of a 12-month exercise inter- vention on leukocyte telomere length: results from the $\mathrm{AL}$ PHA Trial. Cancer Epidemiol 2018;56:67-74.

110. Mason C, Risques RA, Xiao L, Duggan CR, Imayama I, Campbell KL, et al. Independent and combined effects of dietary weight loss and exercise on leukocyte telomere length in postmenopausal women. Obesity (Silver Spring) 2013;21: E549-54.

111. Krauss J, Farzaneh-Far R, Puterman E, Na B, Lin J, Epel E, et al. Physical fitness and telomere length in patients with coronary heart disease: findings from the Heart and Soul Study. PLoS One 2011;6:e26983.

112. Soares-Miranda L, Imamura F, Siscovick D, Jenny NS, Fitzpatrick AL, Mozaffarian D. Physical activity, physical fitness, and leukocyte telomere length: the cardiovascular health study. Med Sci Sports Exerc 2015;47:2525-34.

113. Loprinzi PD, Loenneke JP. Lower extremity muscular strength and leukocyte telomere length: implications of muscular strength in attenuating age-related chronic disease. J Phys Act Health 2016;13:454-7.

114. Iwama H, Ohyashiki K, Ohyashiki JH, Hayashi S, Yahata N, Ando K, et al. Telomeric length and telomerase activity vary with age in peripheral blood cells obtained from normal individuals. Hum Genet 1998;102:397-402. 